\title{
Type 1.5 Split Cord Malformation : A New Theory of Pathogenesis
}

\author{
Mengchun Sun, ${ }^{1,2}$ Benzhang Tao, ${ }^{1}$ Tianbao Luo, ${ }^{3}$ Gan Gao, ${ }^{1}$ Aijia Shang ${ }^{1}$ \\ Department of Neurosurgery, the First Medical Center of Chinese PLA General Hospital, Beijing, China \\ Medical School, ${ }^{2}$ Nankai University, Tianjin, China \\ Department of Neurosurgery, ${ }^{3}$ Yuquan Hospital, Beijing, China
}

To report two cases of type 1.5 split cord malformation (SCM), a subtype of SCM with combined characteristics of types I and II and to review the relevant literature and propose a new possible pathogenetic theory for type 1.5 SCM. A 52-year-old woman had hemicords within a single dural sac with a dorsal bony septum at the L5 level. A 9-year-old boy had hemicords within a single dural sac with a ventral bony septum and fibrous extension at the L3 level. Both patients underwent microsurgical treatments for removing the bony septum, detethering the spinal cord, and sectioning the filum terminale. The surgical procedure revealed an extradural partial bony septum and hemicords within an intact single dural sac in each patient. Both patients were discharged from the hospital without de novo nerve dysfunction. Published cases have validated that types I and II SCM can overlap. We recommend recent type 1.5 SCM as a normative terminology for this overlapping SCM and report two rare cases of this SCM. We propose an associated pathogenesis consisting of uneven distribution and regression to explain type $1.5 \mathrm{SCM}$. Furthermore, we postulate that the amount of condensing meninx primitiva might determine whether the left bony septum has fibrous extensions to the opposite dura in type $1.5 \mathrm{SCM}$.

Key Words : Split cord malformation · Pathogenesis · Embryogenesis · Meninx · Regression.

\section{INTRODUCTION}

Split cord malformation (SCM), a congenital neural tube defect, presents with longitudinally separated functional hemicords. Pang et al. ${ }^{16)}$ classified SCM into two types. In type I SCM (diastematomyelia), the hemicords are divided by a bony sagittal septum within double dural sacs. In type II SCM (diplomyelia), the hemicords are divided by a thin sagittal fibrous septum within a single dural $\mathrm{sac}^{16)}$. However, some authors have reported a few cases demonstrating characteristics of both type I and type II SCM, that is, mixed, intermediate, or composite type $\mathrm{SCM}^{2,11,18)}$. Recently, Meena et al. ${ }^{15)}$ suggested type $1.5 \mathrm{SCM}$ to define these unusual cases. In this report, we present two cases of type $1.5 \mathrm{SCM}$ and review the relevant literature. We also discuss the previously hypothesized pathogenesis and propose a new possible pathogenetic theory.

- Received : December 23, 2020 •Revised : March 6, 2021 •Accepted : April 28, 2021

- Address for reprints : Aijia Shang

Department of Neurosurgery, the First Medical Center of Chinese PLA General Hospital, 28 Fuxing Road, Haidian District, Beijing 100853, China

Tel : +86-10 66875540, Fax : +86-10 57976556, E-mail : shangaj@126.com, ORCID : https://orcid.org/0000-0003-0002-5331

This is an Open Access article distributed under the terms of the Creative Commons Attribution Non-Commercial License (http://creativecommons.org/licenses/by-nc/4.0) which permits unrestricted non-commercial use, distribution, and reproduction in any medium, provided the original work is properly cited. 


\section{CASE REPORT}

\section{Case 1}

A 52-year-old woman had been suffering from constipation since 2012. She experienced pain in the dorsum of both lower limbs (more severe on the left) and numbness of the left foot in 2019. Standing up after sedentariness induced these symptoms. Uroschesis occurred at the end of 2019. The patient was admitted to our department in July 2020. A physical examination revealed a lumbosacral dermal sinus with central hyperpigmentation and tenderness (Fig. 1A), a weakened anal reflex, and intact sensory functions. Muscle strength of the four limbs was grade 5/6. Magnetic resonance imaging (MRI)

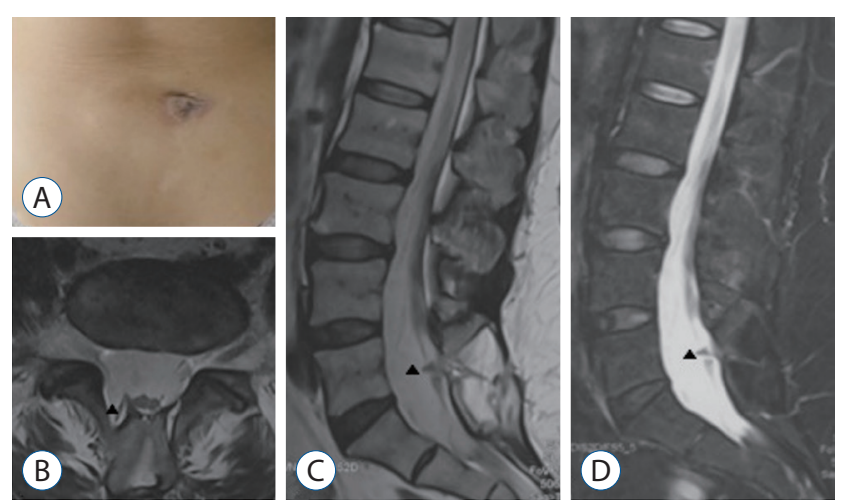

Fig. 1. The lumbosacral dermal sinus (about $4 \times 4 \mathrm{~cm}$ ) with central hyperpigmentation (A). Magnetic resonance imaging suggesting a dorsal bulging lesion (arrowhead) at the $L 5$ level and a low conus at the S1 level (B : axial T1-weighted sequences; $C$ : sagittal T1-weighted sequences; $\mathrm{D}$ : sagittal T2-weighted sequences).
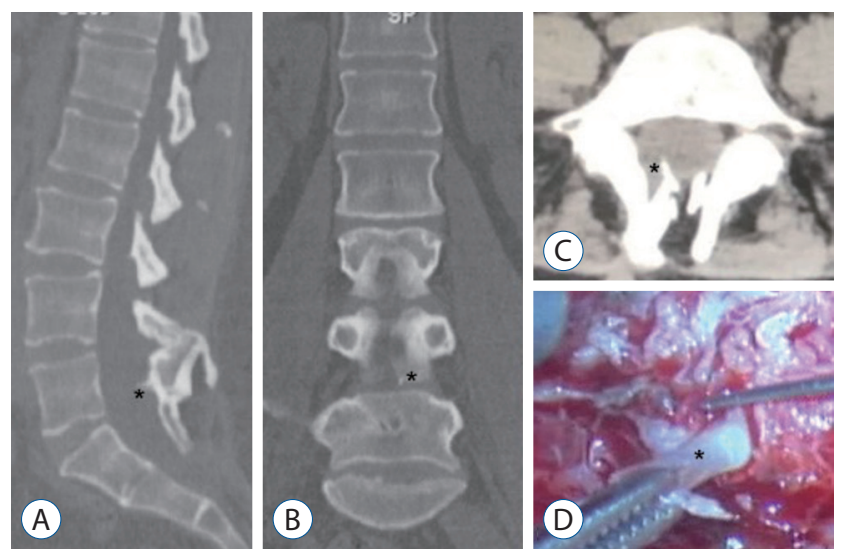

Fig. 2. Computed tomography suggesting a dorsal bony septum (asterisk) at the L5 level (A : sagittal view; B : coronal view; C : axial view). A partially resected dorsal bony septum (asterisk) found intraoperatively. Its base was sectioned during the primary laminectomy (D). demonstrated a dorsal bulging lesion at the L5 level, hemicords within a single dural sac, and a low conus at the S1 level (Fig. 1B-D). Computed tomography (CT) revealed a dorsal bony septum at the L5 level (Fig. 2A-C). The patient underwent a single-stage microsurgery for resecting the dermal sinus and the bony septum, detethering the spinal cord, and sectioning the filum terminale. During the surgical procedure, we found a sinus tract communicating with the intradural space, a dorsal bony septum pointing to the midline of the dural sac without penetrating it (an intact single dural sac) (Fig. 2D), and a thickened and tight filum terminale. No fibrous extension from the bony septum to the ventral dura was noted. The patient was discharged from the hospital 14 days postoperatively without de novo nerve dysfunction.

\section{Case 2}

A 9-year-old boy was found to have asymmetric shoulders (higher on the right) and daily urine suppression since March 2020. He was diagnosed with scoliosis and butterfly vertebra at the T4 level by radiography and CT examinations at a local hospital. He was admitted to our department in August 2020 for surgical treatment. A physical examination revealed a wrinkled lumbosacral cutaneous pit without hair. Preoperative MRI demonstrated a ventral spinous lesion at the L3 level, hemicords within a single dural sac, and a low conus at the L5 level (Fig. 3). CT identified a ventral bony septum at the L3 level (Fig. 4A-C). Three-dimensional CT reconstruction indicated lumbosacral spina bifida (Fig. 4D). We performed a single-stage microsurgery to resect the bony septum, detether the spinal cord, and section the filum terminale. The surgical procedure revealed hemicords within a single dural sac (Fig. $5 \mathrm{~A}$ ), a ventral bony septum with fibrous extension to the dorsal dura (Fig. 5B and C), and a filum terminale lipoma. The bony septum and fibrous extension were completely resected (Fig. 5D). The patient was discharged from the hospital 12 days postoperatively without de novo nerve dysfunction.

\section{DISCUSSION}

We presented two different cases of type 1.5 SCM in this report. Due to the rarity of type $1.5 \mathrm{SCM}$, these two cases are rather valuable. Furthermore, we reviewed the pertinent literature to cover detailed information of published reports, 


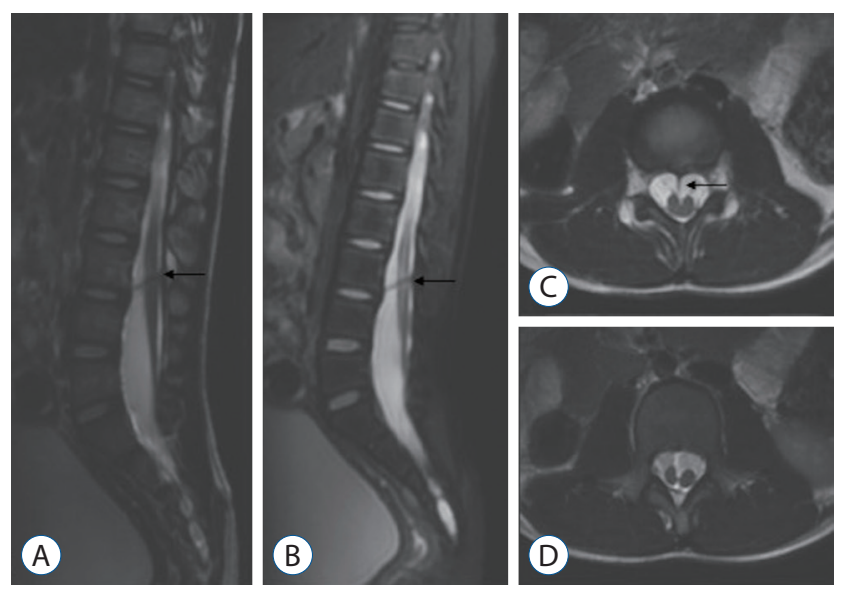

Fig. 3. Magnetic resonance imaging suggesting a ventral spinous lesion (arrow) at the L3 level and a low conus at the L5 level (A : sagittal T1weighted sequences; B : sagittal T2-weighted sequences; C: axial T2weighted sequences). Split spinal cord (D).
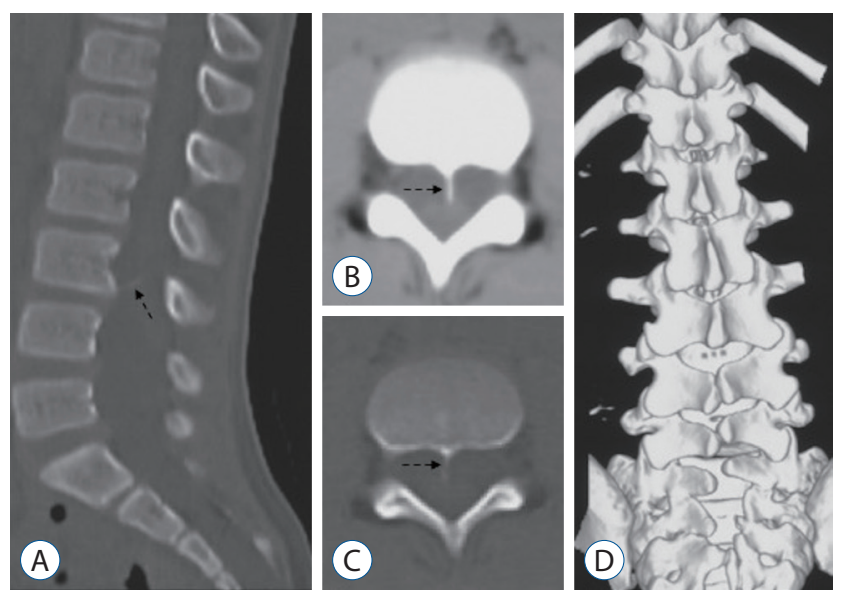

Fig. 4. Computed tomography (CT) demonstrating a ventral bony septum (dotted arrow) at the L3 level (A : sagittal view; B : axial soft-tissue window; $C$ : axial bone window). Three-dimensional $C T$ reconstruction indicating lumbosacral spina bifida (D).

which could help neurosurgeons obtain more knowledge regarding type $1.5 \mathrm{SCM}$.

SCM is a congenital abnormality, within the spectrum of neural tube defects, in which a bony or fibrous septum longitudinally divides the spinal cord into two parts. Due to distinct conceptions, previous authors named SCM with confusing terminology. Diastematomyelia was adopted by Hertwig ${ }^{10)}$ and supported by some other authors ${ }^{12,14)}$, while Bruce et al. $^{4)}$ proposed diastematomyelia for the hemicords with a midline bony spur and diplomyelia for the hemicords without the spur. Other authors, however, preferred diplomyelia regardless of the septal components, ${ }^{9,13,17)}$.

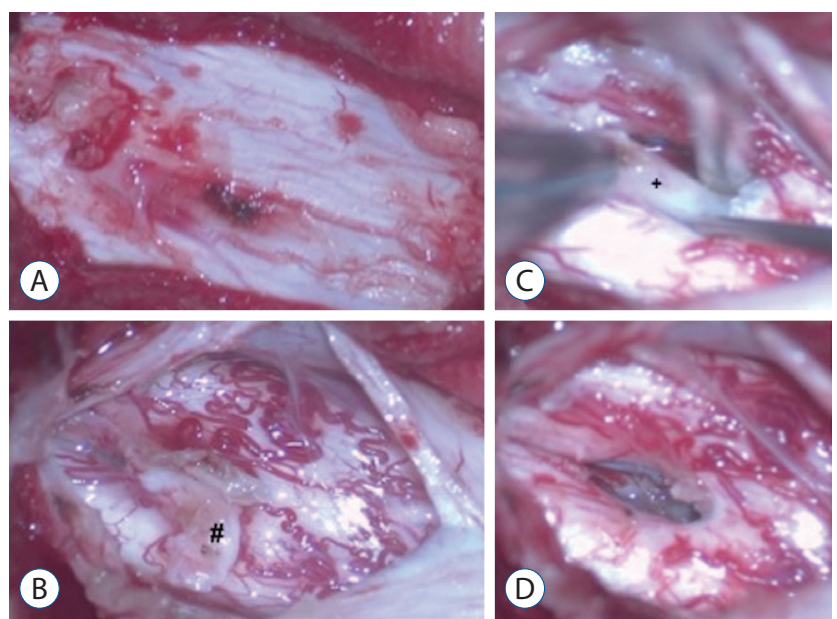

Fig. 5. A : An intact single dural sac. B : A fibrous extension to the dorsal dura (pound). $C$ : A ventral bony septum (cross). D : Complete resection of the bony septum.

In 1992, Pang et al. ${ }^{16)}$ proposed a novel nomenclature that classified SCM into two types : type I SCM (formerly diastematomyelia), presenting with hemicords within double dural sacs split by a bony sagittal septum and type II SCM (formerly diplomyelia), in which hemicords lie in an intact single dural sac with a thin midline sagittal fibrous septum. They also postulated a unified theory to elucidate the pathogenesis of SCM during embryogenesis ${ }^{16}$. According to the unified theory, both types result from a common ontogenetic error ${ }^{16)}$. The meninx primitiva appears over the ventral neural tube and migrates dorsally to wrap it, forming the dural sac. If an abnormal midline fistula of the primitive dura mater forms simultaneously with the normal primitive neurenteric canal (at approximately 21 days' gestational age), the mesenchyme will condense around the fistula, form an endomesenchymal tract, and recruit the meninx primitiva into the tract (around 30 days' gestational age). It is this meninx primitiva that differentiates into the future dura mater and bony septum, and type I SCM develops. If the endomesenchymal tract appears earlier than day 21, the mesenchyme will not collect the meninx primitiva. This results in a thin fibrous septum distinguishable from normal dura mater between the hemicords or type II SCM. Pang et al. ${ }^{16)}$ believed that the unified theory was validated by the fact that all 39 patients with SCM in their series did not manifest combined features of types I and II.

However, some authors have reported a few cases with characteristics of both types I and II SCM, meaning that the lesion incorporated the hemicords within a single dural sac and an 
Type 1.5 Split Cord Malformation I Sun M, et al.

Table 1. Review of the literature

\begin{tabular}{|c|c|c|c|c|}
\hline Study & $\begin{array}{l}\text { Age (years) } \\
\text { /sex }\end{array}$ & Clinical presentation & Radiological presentation & Intraoperative presentation \\
\hline $\begin{array}{l}\text { Chandra et al. } \\
\text { (1999) }\end{array}$ & 9/F & $\begin{array}{l}\text { Right-sided sprengel shoulder deformity } \\
\text { Lumbosacral hair }\end{array}$ & $\begin{array}{l}\text { A dorsal bony septum at L2-3 } \\
\text { Split cord beginning at L2 } \\
\text { Tethered cord at L4 } \\
\text { Low conus at L5 }\end{array}$ & $\begin{array}{l}\text { Thick filum terminale } \\
\text { No fibrous extension }\end{array}$ \\
\hline Erşahin $^{7)}(2000)$ & 14 months/M & Lumbar hypertrichosis & $\begin{array}{l}\text { A dorsal bony septum at L3 } \\
\text { Widened spinal canal } \\
\text { Bifid laminae at L5-S1 }\end{array}$ & $\begin{array}{l}\text { Tight filum terminale } \\
\text { Fibrous bands and dorsal paramedian } \\
\text { roots between the dorsal surface of } \\
\text { hemicords and the dorsal dura } \\
\text { No fibrous extension }\end{array}$ \\
\hline $\begin{array}{l}\text { Basak et al. }{ }^{3)} \\
\text { (2002) }\end{array}$ & $3 / F$ & $\begin{array}{l}\text { Hair-covered mass of the upper dorsal } \\
\text { spine }\end{array}$ & $\begin{array}{l}\text { A dorsal bony septum at C5-6 } \\
\text { Split cord at C3-T1 } \\
\text { Syrinx cavities at C3-T1and T3-T7 }\end{array}$ & No fibrous extension \\
\hline $\begin{array}{l}\text { Akay et al." } \\
\text { (2002) }\end{array}$ & $7 / F$ & Lumbar hair & $\begin{array}{l}\text { A dorsal bony septum at } L 4 \\
\text { Low conus at } L 4\end{array}$ & $\begin{array}{l}\text { Rootlets coming out from the medial } \\
\text { aspect of the hemicords } \\
\text { No fibrous extension }\end{array}$ \\
\hline $\begin{array}{l}\text { Akay et al." } \\
\text { (2002) }\end{array}$ & $2 / F$ & A sacral rigid mass lesion & $\begin{array}{l}\text { A dorsal bony septum at S1 } \\
\text { A bifid lamina at } \mathrm{S1} \\
\text { Conus medullaris at coccyx }\end{array}$ & $\begin{array}{l}\text { Rootlets coming out from the dorsal } \\
\text { medial aspect of the hemicords } \\
\text { Thick filum terminale } \\
\text { Fibrous ligaments lying on the dorsal dura } \\
\text { No fibrous extension }\end{array}$ \\
\hline $\begin{array}{l}\text { Van Aalst et al. }{ }^{21)} \\
(2005)\end{array}$ & $15 / M$ & $\begin{array}{l}\text { Walking difficulties } \\
\text { Pain in the lower extremities, scoliosis }\end{array}$ & A dorsal bony septum at $\mathrm{L} 3-\mathrm{L} 4$ & $\begin{array}{l}\text { Arachnoidal adhesions between the } \\
\text { hemicords } \\
\text { Fibrous extension to the ventral dura }\end{array}$ \\
\hline $\begin{array}{l}\text { Singh et al. } \\
\text { (2011) }\end{array}$ & $1 / F$ & $\begin{array}{l}\text { Hair over the middorsal spine with } \\
\text { hyperpigmentation }\end{array}$ & $\begin{array}{l}\text { A bony septum at T5-T9 } \\
\text { A ventral bony septum at T11 } \\
\text { Split cord at T2-L1 } \\
\text { Low conus at L3-4 }\end{array}$ & $\begin{array}{l}\text { Hemicords with separate dura sacs at T2-L1 } \\
\text { Hemicords with a single dura sac at T11 } \\
\text { Thick filum terminale } \\
\text { No fibrous extension }\end{array}$ \\
\hline $\begin{array}{l}\text { Salunke et al. }{ }^{18)} \\
\text { (2011) }\end{array}$ & $7 / M$ & $\begin{array}{l}\text { A lipomatous swelling } \\
\text { Lumbar hypertrichosis } \\
\text { Weakness of the left lower limb }\end{array}$ & $\begin{array}{l}\text { A ventral bony septum at lower } \\
\text { dorsal level } \\
\text { Bifid laminae }\end{array}$ & $\begin{array}{l}\text { The paramedian nerve roots attaching } \\
\text { to one another } \\
\text { Sinus tract extending extradurally } \\
\text { No fibrous extension }\end{array}$ \\
\hline $\begin{array}{l}\text { Salunke et al. } \\
\text { (2011) }\end{array}$ & $1 / \mathrm{M}$ & $\begin{array}{l}\text { A small midline swelling at the lower } \\
\text { back }\end{array}$ & $\begin{array}{l}\text { A lumbosacral dorsal bony septum } \\
\text { Low conus to the sacrum }\end{array}$ & Fibrous extension to the ventral dura \\
\hline $\begin{array}{l}\text { Garg et al. }{ }^{8)} \\
(2015)\end{array}$ & 10 months/F & $\begin{array}{l}\text { Lumbar midline hair } \\
\text { Lower limbs moving less } \\
\text { Scoliosis }\end{array}$ & $\begin{array}{l}\text { A ventral bony septum at L2-L3 } \\
\text { Lumbosacral spinal dysraphism } \\
\text { Low conus at L3 }\end{array}$ & $\begin{array}{l}\text { Thick filum terminale } \\
\text { No fibrous extension }\end{array}$ \\
\hline $\begin{array}{l}\text { Meena et al. }{ }^{15)} \\
(2020)\end{array}$ & $11 / M$ & Low back pain & $\begin{array}{l}\text { A ventral bony septum at T12-L1 } \\
\text { Split cord from T11 to the cord ending } \\
\text { Low conus at L3-L4 } \\
\text { Hypoplastic } T 10-L 2 \text { vertebral body }\end{array}$ & $\begin{array}{l}\text { Thick filum terminale } \\
\text { No fibrous extension }\end{array}$ \\
\hline Present case 1 & $52 / F$ & $\begin{array}{l}\text { A lumbosacral dermal sinus with central } \\
\text { hyperpigmentation and tenderness } \\
\text { Pain on the dorsal side of both lower limbs } \\
\text { Numbness of the left foot }\end{array}$ & $\begin{array}{l}\text { A dorsal bony septum at L5 } \\
\text { Low conus at } \mathrm{S1} \\
\text { Lumbosacral spina bifida }\end{array}$ & $\begin{array}{l}\text { Sinus tract communicated with intradural } \\
\text { space } \\
\text { Thick and tight filum terminale } \\
\text { No fibrous extension }\end{array}$ \\
\hline Present case 2 & 9/M & $\begin{array}{l}\text { Asymmetric shoulders } \\
\text { Scoliosis } \\
\text { A lumbosacral wrinkled cutaneous pit } \\
\text { Urine suppression }\end{array}$ & $\begin{array}{l}\text { A ventral bony septum } \\
\text { Low conus at L5 } \\
\text { Butterfly vertebra at T4 } \\
\text { Lumbosacral spina bifida }\end{array}$ & $\begin{array}{l}\text { Filum terminale lipoma } \\
\text { Fibrous extension to the dorsal dura }\end{array}$ \\
\hline
\end{tabular}

$\mathrm{F}$ : female, $\mathrm{M}$ : male 
extradural partial bony septum ${ }^{1,3,5,7,8,15,18,19,21)}$. We reviewed the literature, and 13 pertinent cases are listed in Table 1.

There is a lack of consensus on the terminology for this combined SCM, whose terminology includes mixed $\mathrm{SCM}^{18}$, intermediate $\mathrm{SCM}^{11)}$, and composite $\mathrm{SCM}^{16)}$. Recently, Meena et al. ${ }^{15)}$ proposed type 1.5 SCM to define this unusual variation. Based on the location of the bony septum, they classified type 1.5 SCM into two subtypes: type 1.5a SCM, with the vertebral plate arising, and type $1.5 \mathrm{~b}$ SCM, with the vertebral body arising ${ }^{15)}$. We believe that this simplified terminology adequately describes the characteristics of this unusual SCM. Referring to this method, we classified our case 1 as type $1.5 \mathrm{a}$ SCM and case 2 as type $1.5 \mathrm{~b}$ SCM. We hope that this terminology will be adopted by more authors and applied in future studies to unify the nomenclature.

Different authors have held various views to explain the pathogenesis of type 1.5 SCM. Vaishya and Kumarjain ${ }^{20)}$ supported the unified theory and considered that all variants of SCM shared a common pathogenesis in which the proportion of the meninx primitiva was the only influencing factor determining the SCM type : the more meninx primitiva cells present in the endomesenchymal tract, the more complete is bony septum and dura formation. Chandra et al. ${ }^{5}$ reported a case of dorsal bony septum originating from the vertebral arch. They questioned the unified theory in which the bony septum should develop from the vertebral body where the migration of the meninx primitiva begins ${ }^{16)}$, and hypothesized that the meninx primitiva first migrates along the lateral side of the hemicords, accumulates dorsally, and returns along the endomesenchymal tract dorsoventrally, then forms a dorsal bony septum $^{5}$. In the unified theory, the bony septum and hypertrophic fusion of adjacent laminae should co-exist at the same level in type I SCM, because the meninx primitiva in the endomesenchymal tract could simultaneously induce both lesions $^{16)}$. Salunke et al. ${ }^{18)}$ reported two cases of type I SCM with normal laminae; hence, they doubted the value of the meninx primitiva in forming the bony septum and pointed out a possible role of the pluripotent mesenchyme. They also surmised that the regression of the endomesenchymal tract might cause type $1.5 \mathrm{SCM}^{18)}$.

To explain the formation of all subtypes of type $1.5 \mathrm{SCM}$ described in previous reports and our cases, we postulate an associative pathogenesis of type $1.5 \mathrm{SCM}$, consisting of uneven distribution of meninx primitiva and regression of the bony septum. In case 1, we intraoperatively found a dorsal bony septum at the L5 level and fused laminae of L4 and L5. Case 2, however, had normal laminae opposite to the ventral bony septum. We conjecture that uneven distribution of the meninx primitiva between the hemicords might cause less cells of the meninx primitiva to mix with the neural arch cells, which weakens the sclerosing effect ${ }^{2)}$, resulting in normal laminae without hypertrophic fusion. This uneven distribution could also explain Salunke et al.'s cases ${ }^{18)}$. Case 2 had a fibrous extension from the bony septum to the opposite dura, but case 1 did not. We hypothesize the regression of the bony septum as a possible mechanism for this left fibrous extension because some studies have validated that regression plays a key role in neurulation and neural tube development ${ }^{6,22)}$. In other words, type 1.5 SCM might be derived from type I SCM. In type I SCM, with uneven distribution, less meninx primitiva forms a less stable part of the bony septum. With some unknown factors, this unsubstantial part might regress, leaving a half bony septum. In case 2, we consider that relatively fewer cells of the meninx primitiva near the neural arch formed neither hypertrophic laminae nor a solid dorsal bony septum. Some factors might drive the dorsal part to regress into a fibrous extension (Fig. 6A). In case 1, it is possible that few meninx primitiva cells exist around the vertebral body, resulting

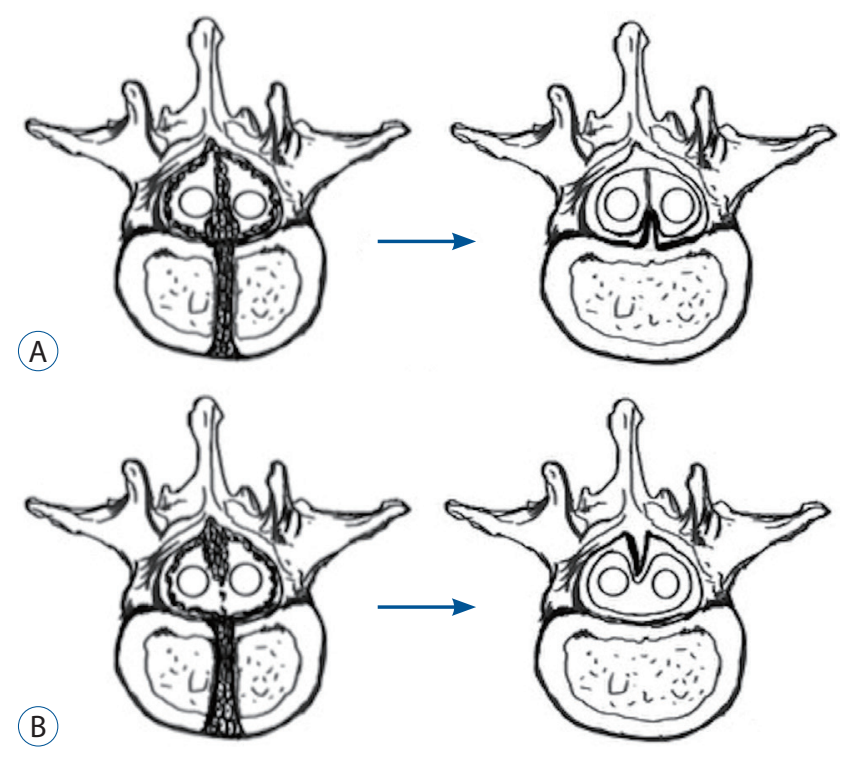

Fig. 6. A relatively lower proportion of meninx primitiva near the neural arch regressing into a fibrous extension from the ventral bony septum in case 2 (A). Few meninx primitiva cells existing around the vertebral body, resulting in a regressed dorsal bony septum without any ventral fibrous extension in case 1 (B). 
in a remnant dorsal bony septum without any ventral fibrous extension (Fig. 6B), which could also explain the case presented by Chandra et al. ${ }^{5}$. Therefore, we postulate that the presence of a fibrous extension might depend on the amount of condensing meninx primitiva. Considering that type 1.5 SCM is extremely rare, we regard regression to be accidental. Pang et al. ${ }^{16)}$ reported that type II SCM was more frequent than type I SCM (around 60\% and 40\%, respectively). Hence, we believe that type II SCM in which only fibrous septa exist should not regress from type I SCM. The pathogenesis of type I and II SCM defined in the unified theory should be conceivable, and our associative theory is only responsible for type 1.5 SCM. To explicitly describe the true mechanisms, an experimental model of embryogenesis may be necessary in the future.

\section{CONCLUSION}

In addition to the unified theory, types I and II SCM could overlap. We recommend type $1.5 \mathrm{SCM}$, as proposed by Meena et al. ${ }^{15)}$, as a normative terminology for this overlapping SCM. We hypothesize an associated pathogenesis consisting of uneven distribution and regression to explain type 1.5 SCM. Furthermore, we postulate that the amount of condensing meninx primitiva might determine whether the bony septum has a fibrous extension to the opposite dura in type 1.5 SCM. We believe that the application of type 1.5 SCM could provide a better classification for neurosurgeons to clarify the type, and the novel possible pathogenesis of type $1.5 \mathrm{SCM}$ may provide a new idea for revealing the origin of SCM.

\section{CONFLICTS OF INTEREST}

No potential conflict of interest relevant to this article was reported.

\section{INFORMED CONSENT}

Informed consent was obtained from all individual participants included in this study.

\section{AUTHOR CONTRIBUTIONS}

\author{
Conceptualization : MS, BT, AS \\ Data curation : BT, TL, GG \\ Formal analysis : MS \\ Methodology: MS, TL \\ Project administration : GG, BT, AS \\ Visualization : MS, AS \\ Writing - original draft : MS \\ Writing - review \& editing: BT, AS
}

\section{ORCID}

$\begin{array}{ll}\text { Mengchun Sun } & \text { https://orcid.org/0000-0003-4184-5395 } \\ \text { Benzhang Tao } & \text { https://orcid.org/0000-0002-0677-3296 } \\ \text { Tianbao Luo } & \text { https://orcid.org/0000-0001-5374-0844 } \\ \text { Gan Gao } & \text { https://orcid.org/0000-0001-7090-5583 } \\ \text { Aijia Shang } & \text { https://orcid.org/0000-0003-0002-5331 }\end{array}$

\section{References}

1. Akay KM, Izci Y, Baysefer A : Dorsal bony septum: a split cord malformation variant. Pediatr Neurosurg 36 : 225-228, 2002

2. Akay KM, Izci Y, Baysefer A, Timurkaynak E : Composite type of split cord malformation: two different types at three different levels: case report. J Neurosurg 102(4 Suppl) : 436-438, 2005

3. Basak M, Ozel A, Erturk M : An unusual case of diastematomyelia. Presence of one dural sheath associated with a bony spur. Acta Radiol 43 : 626, 2002

4. Bruce $A, M^{\prime}$ Donald S, Pirie JHH : A second case of partial doubling of the spinal cord. Rev Neurol Psychiatr $4: 6,1906$

5. Chandra PS, Kamal R, Mahapatra AK : An unusual case of dorsally situated bony spur in a lumbar split cord malformation. Pediatr Neurosurg 31 : 49-52, 1999

6. Colas JF, Schoenwolf GC : Towards a cellular and molecular understanding of neurulation. Dev Dyn 221 : 117-145, 2001

7. Erşahin $Y:$ An unusual split cord malformation. Pediatr Neurosurg $32: 109,2000$

8. Garg K, Mahapatra AK, Tandon V : A rare case of type $1 \mathrm{C}$ split cord malformation with single dural sheath. Asian J Neurosurg 10 : 226228, 2015

9. Herren RY, Edwards JE : Diplomyelia (duplication of the spinal cord). Arch Pathol 30 : 1203-1213, 1940

10. Hertwig 0 : Urmund und spina bifida. Archiv f mikrosk Anatomie $39: 353-502,1892$ 
11. Izci Y, Kural C : Composite type of split cord malformation: rare and difficult to explain. Pediatr Neurosurg $47: 461,2011$

12. Lichtenstein BW : Spinal dysraphism: spina bifida and myelodysplasia. Arch Neur Psych 44 : 792-810, 1940

13. Marr GE, Uihlein A : Diplomyelia and compression of the spinal cord and not of the cauda equina, by a congenital anomaly of the third lumbar vertebra. Surg Clin North Am 24 : 963-977, 1944

14. Maxwell HP, Bucy PC : Diastematomyelia; report of a clinical case. J Neuropathol Exp Neurol 5 : 165-167, 1946

15. Meena RK, Doddamani RS, Gurjar HK, Kumar A, Chandra PS : Type 1.5 split cord malformations: an uncommon entity. World Neurosurg 133 : 142-149, 2020

16. Pang D, Dias MS, Ahab-Barmada M : Split cord malformation: part I: a unified theory of embryogenesis for double spinal cord malformations. Neurosurgery $31:$ 451-480, 1992

17. Pickles $\mathbf{W}$ : Duplication of the spinal cord; an account of a clinical example with a consideration of other reports. J Neurosurg 6 : 324-331, 1949
18. Salunke P, Kovai P, Malik V, Sharma M : Mixed split cord malformation: are we missing something? Clin Neurol Neurosurg 113 : 774-778, 2011

19. Singh PK, Khandelwal A, Singh A, Ailawadhi P, Gupta D, Mahapatra AK : Long-segment type 1 split cord malformation with two-level split cord malformation and a single dural sac at the lower split. Pediatr Neurosurg $47:$ 227-229, 2011

20. Vaishya $S$, Kumarjain $P$ : Split cord malformation: three unusual cases of composite split cord malformation. Childs Nerv Syst 17 : 528-530, 2001

21. Van Aalst J, Beuls EA, Vles JS, Cornips EM, van Straaten HW : The intermediate type split cord malformation: hypothesis and case report. Childs Nerv Syst 21 : 1020-1024, 2005

22. Xu X, Li C, Takahashi K, Slavkin HC, Shum L, Deng CX : Murine fibroblast growth factor receptor 1alpha isoforms mediate node regression and are essential for posterior mesoderm development. Dev Biol 208 : 293-306, 1999 